\title{
$45 \frac{8}{2018}$
}

\section{Through Integral Education to Integral Humanism: Jacques Maritain and His Philosophy of Education Helena Zbudilová}

\begin{abstract}
:
The article focuses on the pedagogical legacy of the work of the Neo-Thomistic philosopher Jacques Maritain (1882-1973). His philosophy of education is sought especially in the perspective of the personal and integral principle of education and with regard to the author's thesis on 'integral education aimed at integral humanism'. The article provides an overview of the author's pedagogical and publishing activities. His work Humanisme intègral (1936) is placed in relationship with the conclusions of the author's fundamental pedagogical works: Education at the Crossroads (1943), The Education of Man (1963), and Pour une Philosophie de l'Education (1959, 1969). The term person as the focal point of Maritain's philosophy of education is viewed by the prism of the demand for the renewal of humanity in the current formation and educational process. Based on critical reflection of the pedagogical theories at that time, the author came to his own definition of formation and education and to the characteristics of the educational goals, and the role of the teacher and pupil/student in the formation and educational process. In addition to these conclusions, the text deals with some of the current problems of contemporary education from the point of view of Maritain's thinking: for example, religious and ethical education, the study of literature (The Great Books), leisure time education, lifelong learning, and specialisation issues. The conclusion is dedicated to the inclusion of Maritain among the top representatives of the Neo-Thomistic orientation of integral personalism. His pedagogical concept brings a holistic approach, builds on perennial educational theory, and represents the pedagogy of values (pedagogy of culture).
\end{abstract}

Key words: Jacques Maritain, integral humanism, theocentric humanism, Neo-Thomistic pedagogy, Neo-Thomistic integral personalism, philosophy of education, principles of education, religious education

If it is true that our chief duty consists, according to the profound saying of the Greek poet, Pindar, in becoming who we are, nothing is more important for each of us, or more difficult, than to become a man. (J. Maritain, Education at the Crossroads, 1943) 
... Till we all come in the unity of the faith, and of the knowledge of the Son of God, unto a perfect man, unto the measure of the stature of the fullness of Christ.

(Ephesians 4:13)

\section{Introduction}

With the onset of the 21st century, it is becoming increasingly clear that the era of globalisation and multiculturalism requires a philosophy of education firmly embedded in humanist tradition. The purpose of humanist formation and education is to restore humanity and lift man to his or her higher levels. It is necessary to ask again, 'Who is a person?' And what kind of humanity must be developed to save him from disintegration in contemporary society? The path of integral education towards integral humanism becomes an urgent message for today's time. As a light, in this context, there comes the work of Jacques Maritain, one of the most prominent representatives of Neo-Thomistic philosophy and Neo-Thomistic personalism. His work represents the interconnection of the world of theology, philosophy, and art and, at the same time, addresses the world of pedagogy with the integral concept of education. P. Georg-Maria Cottier refers to Maritain's work as theo-philosophy: the integrity of theology, philosophy, and mysticism. ${ }^{1}$ According to Carlo Huber, Maritain's political conception and pedagogy have contributed to the unification of Europe. ${ }^{2}$ In the Czech environment, Maritain's pedagogical legacy is rather in the shadow of his political philosophy, and the author's more than forty-year long publishing activity in formation and education remains (with exceptions) rather unknown. Thanks to Miroslav Cipro, Maritain was included in the world teachers' gallery in Cipro's book Prameny výchovy IV (1995). The book offers 24 pages of text dedicated to Maritain's pedagogical concept. This article attempts to reflect on Maritain's philosophy of education (in terms of his essential works published in English and French) in the perspective of pedagogical thinking of the 21 st century.

\section{Maritain as an Educator and Author}

Jacques Maritain did not only write about formation and education but also carried out his own pedagogical activities. In 1914, he became a professor of modern philosophy at the Catholic University of Paris and he worked there until 1939. Since the 1930s, his pedagogical activities have been extended to other countries. From 1932 to 1933, he delivered lectures at the Pontifical Institute of Medieval Studies in Toronto. In 1934, he worked at a university in Santander, Spain. In the early 1940s, Maritain intended to have lectures in New York but then he stayed in the US throughout the Second World War. He lectured at Colombia University, Princeton, Chicago, Yale, and at the University of Notre Dame. His 'Terry Lectures', presented at Yale University in 1943, have entered the history of pedagogy. In the same year, they were published under the title Education at the Crossroads. In 1948, Maritain returned to America. He was appointed a professor at Princeton University and worked there until 1960. In the last decades of his life, he was teaching in Toulouse giving seminars to the members of Little Brothers of Jesus (the congregation inspired by the life and writings of Blessed Charles de Foucauld, which he joined after the death of his wife). ${ }^{3}$ As a teacher, Jacques Maritain was always an example of a person with the philosophical commitment of a Christian thinker.

1 Cf. Helena HREHOVÁ, Morálna filozofia Jacquesa Maritaina: Reflexie o etike a morálke, Trnava: Filozofická fakulta, Trnavská univerzita, 2011, p. 191.

2 Cf. ibid., p. 196.

3 Cf. Klára JELÍNKOVÁ, Jacques Maritain v datech, Salve 2/2006, pp. 119-124. 
In Maritain's inter-war publishing activity one can see as the beginning of his later systematic interest in the issue of a new pedagogical concept. A total of 41 works on formation and education (including magazines) were published. ${ }^{4} \mathrm{He}$ also dealt with this subject in a number of his works on aesthetics, morality, and politics. The first post-war study of the author entitled The Problem of a Public School in France (Le Problème de l'École Publique en France, 1946) concerned the reform of French education. The major pedagogical work is represented by two publications published in English: Education at the Crossroads (1943) and The Education of Man: The Educational Philosophy of Jacques Maritain (1963); and there was one publication published in French: Pour une Philosophie de l'Education (1959 and 1969). The last two mentioned books offer the text of Education at the Crossroads and some identical chapters. Both represent a coherent concept of the philosophy of education. The second edited edition of the 1969 book Pour une Philosophie de l'Education is the final comprehensive systematisation of the author's pedagogical views. ${ }^{5}$

Maritain's reflections on education developed fundamentally between 1940 and 1960 when he lectured at the most prestigious American universities. He philosophised about formation and education during the social crisis and the uncertainties of war and post-war times. It is interesting to observe the first and last edition of his key pedagogical works in terms of their genesis. Education at the Crossroads (1943) is a response to the Second World War. In the book Pour une Philosophie de l'Education (1959), there are reactions to the hippie movement in the 1960s and the 1969 edition also reacts to the 1968 movement in France. If the author warns in the first book of Nazi totalitarianism, the last publication sounds like a warning regarding technocracy, consumerism, the problem of treating man as an object, and the unanchored absolutism of free choice. In his work we find critical responses to contemporary pedagogical trends, especially to (at that time popular) pragmatism. Maritain's metaphor 'education at the crossroads' remains current. Humanist pedagogy is a common platform. But in which direction should we continue, taking into account the current state of society and the crisis of education which is de facto a human crisis? By the way of anthropocentric or theocentric humanism?

\section{Integral Humanism}

Maritain's often quoted thesis 'through integral education towards integral humanism' ${ }^{\prime}$ is an expression of the author's call for a new humanism, a new Christianity. This vision of modern Christianity and the idea of a post-capitalist social order built on a Christian-personalistic basis is presented in the book Humanism Intègral (1936, in Czech under the titles Křestanský humanismus, 1947 and Integrální humanismus, 1967). In this cult book for generations of Catholic intellectuals, new Christianity is integral humanism, the humanism of the Incarnation 'which should be not only motivated but also structured so as to respect the sanctity of the human person. Such a person is rooted in the transcendent, open to the action of grace and to a living relationship with God, who sanctifies and saves.' Integral humanism is unmistakably realised on a theocentric basis, and 'its very essence is to make man more truly human, revealing to him his original size, providing him with participation in everything that can enrich him in nature and in history.'

4 Luz M. IBARRA, Maritain, Religion and Education: A Theocentric Humanism Approach, American University Studies: Peter Lang Publishing Inc., 2013, p. 74.

Miroslav CIPRO, Prameny výchovy. IV, 20. století, Prague: Miroslav Cipro, at his own expense, 1995, p. 171.

6 Jacques MARITAIN, Education at the Crossroads, New Haven: Yale University Press, 1943, p. 88 (translated from the Czech version).

HREHOVÁ, Morálna filozofia Jacquesa Maritaina..., p. 190.

8 Jacques MARITAIN, Integrální humanismus, Rím: Křestanská akademie, 1967, p. 10. 
According to Maritain, the present time is a tragedy of the spirit of the epoch that wanted to break away from God and his law. ${ }^{9}$ Anthropocentric humanism (which sees man as 'the centre of himself' and therefore the centre of all things) is called by Maritain 'inhuman'. He understood its dialectics as a tragedy of humanism. In the book Integral Humanism, which was based on the author's lectures at the University of Poznan and Santander, the author sets out the goal to act 'as Christians' (at the spiritual level) and 'in a Christian manner' (at the political level). ${ }^{10}$ Maritain was one of the inspirers of the Universal Declaration of Human Rights adopted by the United Nations General Assembly in December 1948. One of the cornerstones of this declaration is the right of every person to education. Maritain's thought also influenced UNESCO, in particular regarding the concepts of man, world, and culture. Maritain co-authored the text of the Declaration of the Rights of the Child issued by the United Nations in November 1959. Maritain's ideas of a new humanism have also been addressed by Pope Paul VI, who in his speech in 1965 at the meeting of the Second Vatican Council welcomed the onset of a humanism of 'true and full humanity' (integer homo). ${ }^{11}$ Maritain was also an inspiration to Pope John Paul II, especially in the field of ecumenism. ${ }^{12}$ According to Nikolai Berdyaev, Maritain 'is the first to introduce Thomism into culture. He has also become a key figure in the application of Neo-Thomism to formation and education.

\section{Personalistic View of Education}

Maritain's integral humanism presents a personalistic view of education. The central theme that intertwines through the whole of the author's work is the issue of man and his or her full realisation as an individual in the context of a pluralistic society organised in a democratic system. This key theme is closely related to the subject of formation and education. ${ }^{13}$ Maritain in The Education of Man: The Educational Philosophy of Jacques Maritain defines man in terms of the philosophical-religious dimension of a human being as

a creature gifted by intellect whose highest dignity is in the intellect; as a free individual in a personal relationship with God whose supreme right is voluntary submission to God's law; as a sinful and vulnerable creature called to live as the image of God and according to God and towards the freedom of grace of which the ultimate perfection lies in love. ${ }^{14}$

Maritain continued with the teachings of Thomas Aquinas, and by applying the methodological criterion 'distinguer pour unir' (distinguish to unify, that is, distinguish for the purpose of unification at a higher level), he understands man in his or her fundamental unity but distinguishes him at two levels - as an individual and as a person. This distinction becomes the core of his philosophy of education. The human person and his or her full realisation become the centre of education that is an integral education. By adopting a Thomistic paradigm, Maritain defines man as an individual person, an entity that possesses himself through reason and will, an entity containing the immanent,

9 Juraj LAUKO, Krátký náčrt personalistickej sociálnej filozofie Jacqua Maritaina, Filozofia 3/2005, Filozofický ústav SAV, p. 198.

10 Philippe CHENAUX, Maritain na úsvitu třetího tisíciletí, Salve 2/2006, p. 14.

11 Ibid., p. 13.

12 HREHOVÁ, Morálna filozofia Jacquesa Maritaina..., p. 27.

13 Marek WIESENGANGER, Perspektívy filozofie výchovy podla Jacquesa Maritaina, Acta Fac. Paed. Univ. Tyrnaviensis, Ser. D 15/2011, p. 41.

14 Jacques MARITAIN, The Education of Man: The Educational Philosophy of Jacques Maritain, published by Donald and Idella Gallagher, Notre Dame, Ind: Notre Dame University Press, 1963, p. 7 (translated from the Czech version). 
vital principle of life (inner spiritual principle) open to the outside world. Man is complete and independent; he is an integral being. ${ }^{15}$ Maritain's philosophy of education is based on Thomism, which recognises the integral role of the person's spiritual and metaphysical dimensions. While theocentric humanism is the world of a person, anthropocentric humanism is the world of an individual. Man as a person goes beyond society and the state. As an individual, he is subordinated to society. ${ }^{16}$ Thus, a human being is no longer merely a physical individual but a person of free will, responsible for his or her deeds. Perfect acts are initiated by the grace of God. ${ }^{17}$

The central point of Maritain's philosophy of education is therefore the person and his or her full realisation. We will try to define the basis of his philosophy of education based on answers to the following questions: 'What is formation and education?', 'What are the aims of formation and education?', 'What are the basic dispositions of a pupil?', and 'What role does the teacher play in a formation-educational process?'. Maritain defines formation and education as 'the accompanying of a person in dynamic growth during which he forms himself in the degree of a person receiving at the same time the spiritual heritage of the nation and the civilisation to which he belongs (as well as the secular heritage of generations that in this way can be preserved). ${ }^{18}$ Education is 'the awakening of a person', 'becoming who we are,' 'an art where everyone can become an art work.' ${ }^{19}$

\section{The Objectives of Formation and Education}

Maritain, inspired by the famous quote of the Greek poet Pindar 'Learn what you are and be such', formulates the main goal of education, that is, shaping a person and directing the growing dynamism by which one creates himself. ${ }^{20}$ The first goal of education and training is the acquisition of inner and spiritual freedom: liberation through knowledge, wisdom, goodwill, and love. Being free, becoming oneself, becoming a human being. ${ }^{21}$ Christian education must enable children, young people, and adults to know how they are, to achieve their true form according to the image of God and to become authentically human in order to '...come into the unity of the faith, and of the knowledge of the Son of God, unto a perfect man, unto the measure of the stature of the fulness of Christ' (Ephesians 4:13). The second goal of education is to become a citizen, a full member of society. According to Maritain, the school should primarily teach pupils to think and develop their inner intellectual abilities. ${ }^{22}$ It should ensure the attainment of the personal and social fullness of its graduates thus becoming a preparation for life in a democratic society.

Maritain shaped his philosophy of education based on confrontation with the mistakes of the pedagogical theories at that time. These ideas were first published in the book Education at the Crossroads in the chapter 'The Paradoxes of Education. ${ }^{23}$ The first goal of formation and education was formulated in contrast to the perspective of ateleologism (denial of educational goals), pseudoteleology (misconceptions of the goals, such as the reduction of the person to a whole of physical, biological, and psychological phenomena) and pragmatism (absence of the contemplation dimension and the idea of improvement of the person as a person). The second goal of education

15 Tamtéž, p. 42.

16 Joaquim D'SOUZA, Education to Freedom: Don Bosco and Jacques Maritain in Tandem?, Journal of Philosophy and Education 1/2006, p. 6.

17 CIPRO, Prameny výchovy. IV, 20. století..., p. 165.

18 WIESENGANGER, Perspektívy filozofie výchovy podla Jacquesa Maritaina..., p. 43.

19 MARITAIN, Education at the Crossroads..., pp. 1-9 (translated from the Czech version).

20 Ibid., p. 1.

21 Ibid., p. 11.

22 Ibid., p. 104.

23 Ibid., pp. 22-28. 
and training was based on a critical reflection of sociologism (a person as a function of the society's own goals), intellectualism (a focus on encyclopaedic knowledge and early specialisation), voluntarism (focusing on the isolated education of will and emotions without emphasis on the development of reason), and pandidactism (the belief that everything can be learned). ${ }^{24}$

\section{The Role of Pupils/Students and Teachers}

According to Maritain, a pupil/student (with his or her intellectual ability) is the primary agent, the driving force of the educational process. In the first place is the inner vital principle, the primary dynamic factor working inside the pupil/student ${ }^{25}$ Maritain mentions the five natural dispositions to develop: the love of truth, the love of good and justice, the simplicity and openness of the spirit, respect for work, and the sense of cooperation. ${ }^{26}$ The first source of knowledge, according to Maritain, is intellectual intuition led by the love of truth (being open to the light, per amore cognoscimus - we know by love). ${ }^{27}$ The pupil/student is expected to discover what it means to live a quality authentic life, and that he will (at the same time) create the criteria of authenticity for himself, that is, he will be the educator to himself and has the status of the educated one before himself). ${ }^{28}$

The teacher represents the second dynamic factor in the educational process. The teacher's role lies in the intellectual leadership of the pupil/student, and encouragement of his or her intellectual dispositions with absolute respect for his or her 'vital inner principle.' The teacher's art is that he imitates the paths that natural intelligence uses in its own operations. ${ }^{29}$ According to Maritain, the art of education should be compared to medical art: 'Medicine deals with a living being, an organism that contains inner vitality and the inner principle of health. In other words, medicine is ars cooperativa naturae, the art of help, art in the service of nature. The same applies to education. ${ }^{30}$ The teacher is both a facilitator and an artist who inspires and 'enlightens'. Maritain's metaphors of physicians and artists also refer to the fact that the teacher uses both scientific and artistic methods in his or her work. According to Maritain, the success of education depends more on the personality of the teacher than on the choice of methods and organisational forms. The teacher and pupil/student are similar in nature (they are 'analogous'). The natural activity of the pupil's spirit and the intellectual leadership of the teacher become dynamic factors of education along with the inner desire of the pupil/student (primary dynamic factor and impulse) which represents the main acting force. ${ }^{31}$ The result of education should be a person who 'loves his or her existence' because he feels respect for his or her person, is embedded in a human community that does not oppress him, and can fulfil his or her own aspirations to approach the truth and his or her own urge for good. ${ }^{32}$ Maritain sets out four basic standards for teachers: the liberation of good energies as the best means of suppressing bad ones, focusing on the inner depth of a pupil as a person and his or her pre-conscious spiritual mechanism, ensuring the inner unity of a pupil as a person, and liberating the pupil's intelligence, while, at the same time, not overloading them with unreasonable demands. ${ }^{33}$

\footnotetext{
WIESENGANGER, Perspektívy filozofie výchovy podla Jacquesa Maritaina..., pp. 42-44.

MARITAIN, Education at the Crossroads..., p. 31.

Ibid., pp. 36-38.

Jiří VAČKÁŘ, Jacques Maritain (18. 11. 1882 - 28. 4. 1973) - výročí, Prostor 25/1993, p. 130.

WIESENGANGER, Perspektívy filozofie výchovy podla Jacquesa Maritaina..., p. 55.

CIPRO, Prameny výchovy. IV, 20. století..., p. 165.

MARITAIN, Education at the Crossroads..., p. 30 (translated from the Czech version).

Miroslav CIPRO, Pedagogické směry 20. století v kapitalistických zemích, Prague: SPN, 1966, p. 300.

32 ( ) Andrej RAJSKÝ, Univerzitné vzdelavanie v koncepte integrálneho humanizmu Jacquesa Maritaina (online), available at: http://pdf. truni.sk/zborniky/evsuv-2004/sekcia2/Rajsky.pdf, cited $19^{\text {th }}$ May 2018.

33 Jacques MARITAIN, Pour une philosophie de l'education, Paris: Fayard, 1969, pp. 53-62.
} 


\section{1 \\ Basic Principles of Education}

Marek Wiesenganger, in his study Perspektivy filosofie výchovy podle Jacquesa Maritaina (Perspectives of the Philosophy of Education by Jacques Maritain), defines the author's three basic principles of education: the principle of a person and integral education, formation and education as a process of becoming free, and the principle of pluralism. There is a need to develop personality and individuality, but the priority is the principle of a person. According to Maritain, the concept of an individual person is the basis of integral education. The second principle is to become free through formation, education, and culture. This is not freedom in the sense of choice. It is the liberation of the constitutive principles of inner life (cognition, love) but also liberation at the level of the unity of inner life. ${ }^{34}$ The third principle, the principle of pluralism, is one of the aspects of democracy on which free formation and education are built. At the level of the individual the pluralistic principle is the search for and realisation of the path of personal uniqueness, and at the level of society it is discovering and the realisation of ways of mutual co-existence. In the book Pour une Philosophie de l'Éducation, Maritain reached the necessity of introducing a common democracy and education credo: a human and temporal credo and a philosophical or religious credo. The combination of the pluralistic principle (respect for freedom) and the principle of unity (search for truth) is, according to Maritain, carried out in the concept of integral humanism, which allows one to develop his or her metaphysical dignity on the dialectical axis 'from somewhere to somewhere else. ${ }^{35}$

\section{Current Incentives}

The confrontation with the pedagogical theories of that time raised Maritain's interest in the issues of formation and education in various areas. Given the limited scope of this article, we will only focus on a number of topics relevant to the current needs of today's education. These are liberal education and humanities (especially literature teaching), the issue of specialisation in individual levels of education, leisure time education, lifelong learning, and ethical and religious education.

\section{Liberal Education and the Issue of Specialisation}

Jacques Maritain was a promoter of liberal education (humanitatis and artes liberales), which aims to achieve a full and valuable human life along with the development of culture and civic spirit. Maritain promotes the principle of uniting the unity of the substantive content of the subject matter (the factologically indisputable curriculum) and the differentiation of the ideological basis of teaching. The subjects are divided into 'pre-liberal', that is, a kind of general education (grammar, logic, languages and historical disciplines) and 'liberal', that is, general education. There is the trivium (rhetoric, literature with poetry, and music with arts) and quadrivium (mathematics, physics with the natural sciences, philosophy, and morality). Higher education should, according to him, be devoted to teaching the humanities and natural sciences with a focus on practising logical and rational thinking. This is a study of general subjects aimed at content and preparation for work and leisure (without early specialisation). ${ }^{36}$ Elementary and secondary education should mainly provide an education for life. Early specialisation prevents the full development of human 
potentiality: it is a tool of dehumanisation. In particular, high school study programmes should, according to Maritain, partly give up the functional vision of the rapid integration of students into the professional world of work, and pay more attention to the person and his or her shaping into a cultural personality. ${ }^{37}$ Maritain criticises the intellectualism of his time for abandoning universal values and focusing on scientific and technical specialisation. At the secondary and pre-university level, education should provide students with a general education and lead to the formation of the student into a real person. According to Maritain, natural talent, reinforced by general education, liberates and expands one's spirit. ${ }^{38}$ The university should be focused on the universe (the universe of things) and it should be open to the whole. For this reason, philosophy occupies a completely privileged position within university studies. It should include epistemology, philosophy of nature, ethics, and political and social philosophy. From Maritain's point of view, specialisation and professionalism, as they are, belong to higher professional schools and universities.

\section{Teaching Literature (The Great Books)}

Jacques Maritain calls for a greater focus on shaping the person into a cultural personality through the humanities and art. These are capable of presenting universal values and enabling man to live spiritually, opening him to transcendence. The reflection of art is through Maritain's entire philosophical work. In Creative Intuition in Art and Poetry (originally published in 1953, in Czech in 1955), Maritain analyses the relationship of art and beauty which should 'bring harmonious spiritual joy. ${ }^{39}$ The basic method of the educator is to present the truth, emphasising the aesthetic dimension of beauty and the moral dimension of good. Truth is depicted in literary works of world literature, so the hermeneutics of great literary works plays an important role. Maritain, along with Robert Hutchins and Mortimer Adler, supported the integration of the reading of works by the great classics of Western literature into a college degree programme. ${ }^{40}$ The beginnings of the American Great Books movement are linked to the University of Chicago, and today the 'The Great Books Programme' is a part of the studies offered by some universities in the US, Canada, and Europe. The programme focuses on the reading and interpretation of important literary works not only of Western civilisation. According to Maritain, by reading Homer, Sophocles, Marcus Aurelius, Dante, Cervantes, Shakespeare, Racin, Goethe, Dostoyevsky, etc., the minds of students are filled with 'caritas humani generis. By studying works of classics, with a special focus on ancient literature and culture, students return to the subject of man and serious existential questions. It is one of the best means of understanding the essence of humanity, the phenomenon of love, heroism, and the highest values of being. It is an effective tool for the versatile cultivation of the human spirit at the intellectual and moral level. Studying ethics through classic works seems to be much more effective than the theoretical studies of the subject itself. Reading brings not only the knowledge of truth but also the experience of truth and beauty. Aesthetic experience is another knowledge that is realised in the work. Maritain characterises it as a piece of knowledge of a particular kind, specifically, a piece of knowledge through unity. ${ }^{41}$ Recognition through unity or per connaturality is knowledge through empathy or affection, resonance in the subject. ${ }^{42}$ Western civilisation could, through the reading of classics, rediscover its roots and the Christian

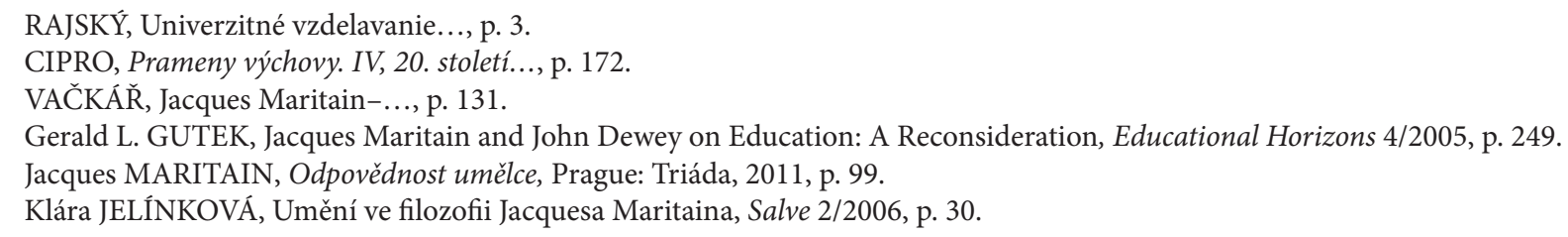


principles of its culture. According to Maritain, secondary schools should develop free arts, and universities then should continue with the studies of Greek and Latin classics as part of a multi-year philosophy, including an optional subject aimed at studying the cultural and intellectual heritage of western civilisation in the form of the canon of western culture (The Great Books).

\section{Leisure Time Education, Lifelong Learning}

When defining the structure of the school curriculum, Maritain distinguishes between 'games' and 'study'. In addition to sports and physical education, 'games' also includes handicraft manual activities. Additionally, it includes a wide range of different practical activities that, rather than a subject of formal education, should be a playful activity of interest. ${ }^{43}$ Maritain's interest was greatly targeted at leisure activities. Their meaning was seen in the freedom and joyful spontaneity that can be experienced by a child who is doing them. Paradoxically, the out-of-school sphere involving leisure activities influences the pupil by 'an activity that is more important than school education itself' ${ }^{44}$ According to Maritain, there are things that cannot be taught in any school or course. These are vital life issues, such as establishing a relationship of friendship and love, achieving wisdom. They are not a matter of teaching or training, they are a gift and freedom. In Education at the Crossroads, Maritain predicts that 'leisure time will be a major problem for the world of tomorrow. ${ }^{45}$ Leisure time education is a very good tool for the growth of what is most humane in man. According to Maritain, formation and education do not end at the school-gates but 'continues till the end of life'. Speaking about lifelong learning, Maritain expressed his critique of the traditional belief that the whole process of forming a human being can be embedded in the microcosm of school education. He sees education 'as a large factory where the entrance gate is entered by a small child in the form of raw material and through the exit leaves a young man in his twenties in the form of a man happily made. ${ }^{46}$

\section{Ethical Education}

Maritain's ideas on morality are summarised in his pedagogical-didactic work Neuf Leçons sur les Notions Premières de la Philosophie Morale (1951) in which his ideas following Aristotle and Tomas Aquinas are systematised. ${ }^{47}$ If, according to Maritain, art is true leading and making, ethics is a true quality of action as stated in Art et scolastique (1920). ${ }^{48}$ The pillar of the code of ethics is, according to him, the Ten Commandments of God which include the entire natural law. The natural law is, at the same time, the universal one. ${ }^{49}$ One has to be human, above all, in a moral sense. Maritain emphasises the moral formation of the pupil/student with regard to the development of the 'caritas humani generis'. Internal freedom has to be acquired in the context of the common good. As the author states in The Education of Man: The Educational Philosophy of Jacques Maritain, the family is primarily responsible for the moral formation of a child. The responsibility of the school lies in the intellectual development of the pupil/student, in the education of his or her practical reason, not in the targeted education of the will and in the direct development of moral

\footnotetext{
CIPRO, Prameny výchovy. IV, 20. století..., p. 174.

SOUZA, Education to Freedom..., p. 23 (translated from the Czech version).

MARITAIN, Education at the Crossroads..., p. 89 (translated from the Czech version).

CIPRO, Prameny výchovy. IV, 20. století..., p. 166.

HREHOVÁ, Morálna filozofia Jacquesa Maritaina..., p. 186.

Jacques MARITAIN, Umění a scholastika, Olomouc: Knihovna filosofické revue, sv. V., 1933, p. 25.

HREHOVÁ, Morálna filozofia Jacquesa Maritaina..., p. 203.
} 
virtues. ${ }^{50}$ According to Maritain, 'morality is soaked in intelligence' and the goal of education is to awaken the moral intelligence of a student. ${ }^{51}$ Maritain is convinced that education belongs to ethics and practical wisdom; education itself is an ethic art. ${ }^{52}$

\section{Religious Education}

The highest form of moral education is religious education. Maritain's philosophy of education is an educational concept that integrates all dimensions of the human person, including a person like Homo religiosus, that is, a spiritual-religious being. It focuses on the human person as a whole. It seeks to reintegrate the person with the Creator and to integrate all the people in a community or society who would share a common belief in God and a common interest in the welfare of mankind..$^{53}$ Maritain was not a theologian but a philosopher. When he proposed his concept of the philosophy of education, the concept of Christian education did not reach today's level of sophistication. Maritain, inspired by the teachings of Thomas Aquinas, built his philosophy on the thesis that 'man is able to know the truth with certainty'. ${ }^{54}$ Through his work, he showed the priority of spiritual and metaphysical values in man's life and fought for a new integral human civilisation, finding his true spiritual resources in the Gospel and in self-awareness in the spirit of the Gospel. ${ }^{55}$ Man now calls himself a Christian, more or less secularised. ${ }^{56}$ Everyone (including the materialist and the atheist) is de facto a Christian in the ethical and cultural sense if his or her morality is as human as the morality of the Bible. ${ }^{57}$ His or her culture is a Christian culture. Without the basic knowledge of theology, one cannot fully understand traditional or modern Western culture, nor the history of the Middle Ages and the Modern Age. An important milestone in Maritain's reflection on religious education was a lecture at Kent School in 1955, which was published by Yale University in The Christian Idea of Education. This lecture later became part of the book Pour une Philosophie de l'Education and The Education of Man: The Educational Philosophy of Jacques Maritain. The author deals with the basic features of Christian education. Religious education, according to Maritain, is aimed at achieving spiritual freedom and the true form of a person according to the image of God. The main goal of Christian education is the education of spirit, thought, and conscience. It does not mean only the acquisition of knowledge. It also includes value orientation; it is also moral education. Maritain puts an emphasis in the early stages of education on the revival of reason and moral strength..$^{58}$ Religious education should enhance spirituality in the sense of a spiritual path and self-discovery, and it should direct pupils/students to search for the meaning of their life. The self-improvement of man comes through love. And it is ultimately the love of God that transforms man into a person. In the book Integral Humanism, Maritain calls for finding the right place for Christian teaching in the structure of the educational system, as religion is a necessary part of school education. ${ }^{59}$ According to Maritain, the child has the right to be equipped with religious knowledge and also with other knowledge essential

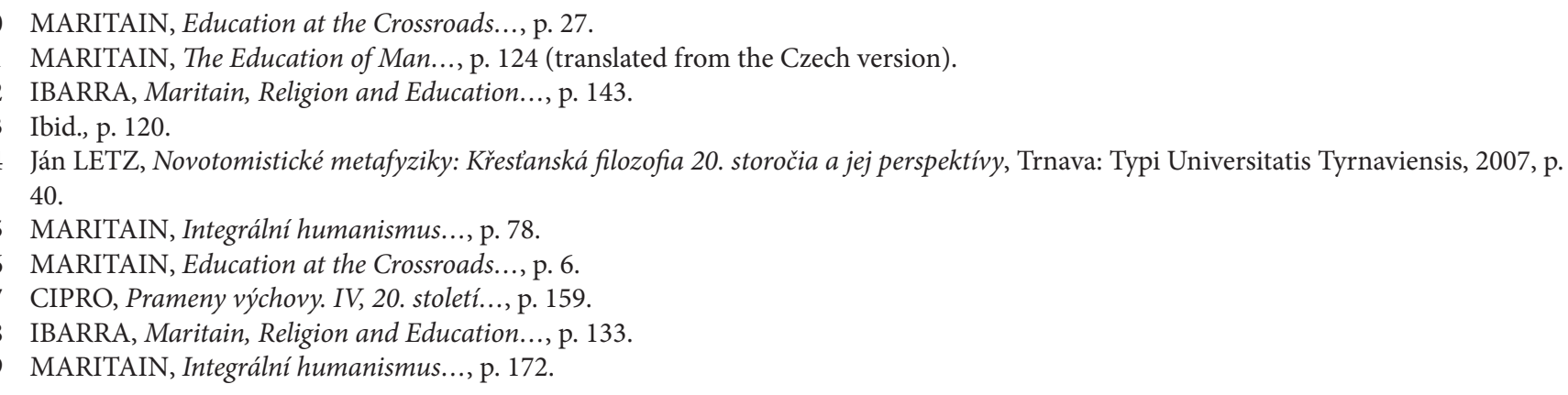


to a person's life. In addition to promoting religious education at religious schools, he pursued education with a religious focus in the humanities through a uniform curriculum and facultative religious education at other schools. The content of all these subjects must be associated with the spirit of Christianity. Becoming acquainted with Bible content should be a part of education at all types of schools. Religious education should not be closed inside itself but should be broadened to its wider integration into the intellectual interests and personal life of pupils/students. Maritain even recommends participation in the liturgical life and meetings of pupils/students, for example, in order to read the Gospel ${ }^{60}$ According to Maritain, there is no reason to exclude teaching theology from the offer of any university study. Theological subjects should remain the subject of free choice. ${ }^{61}$ Students with an atheistic focus should be allowed, for example, to study Religious Studies. As Maritain states in Education at the Crossroads, if this offer does not find a response amongst students, they will be allowed to remain partly uneducated to their own satisfaction. ${ }^{62}$ According to Maritain, theology and philosophy must be the cornerstone of studies at theological faculties. At the same time, he advocates the introduction of an additional complement of higher education - spirituality centres, peace centres that, in the spirit of European traditions of spiritual exercise, give students space to deepen their own mystical verticality. ${ }^{63}$

\section{Life of Prayer, Mysticism}

Karel Šprunk, the philosopher and Maritain's follower, chairman of the Czech Society of Jacques Maritain (founded in 1993), characterised Maritain's efforts in the following words: 'Jacques Maritain looks for a way to penetrate all things with the light of the Gospel, to develop all human values and (at the same time) life itself which is the gift of the Holy Spirit. ${ }^{\prime} 4$ According to Maritain, the world will be fully humanised only in Christ. As Thomas Aquinas said, 'Christ's human nature is the sovereignly adapted pedagogy that leads to his divinity'. ${ }^{65}$ Man only fulfils his or her human destiny in Christ (man and God). In his latest book, The Peasant of the Garonne (La Paysan de la Garonne, 1966), Maritain states that in the holistic conception of the person, the most important thing is the life of prayer and unity with God. ${ }^{66}$ Maritain and his wife Raïssa lived by inner prayer. ${ }^{67}$ In the Book Cercle d'Études Jacques et Raïssa Maritain (1973), Maritain marks the mercy of contemplation as a pleasant and living entering into Jesus's states of being. ${ }^{68} \mathrm{He}$ considers prayer, in the world as God created it, as necessary: 'If we do not pray, we cannot grow in Christian life nor receive all good things, true brotherly love, inner peace and joy, and Job's manure and its worms - the earthly things which enable us to enter eternal life here on Earth. ${ }^{69}$ Mystical experience is then the experience 'which takes possession of the absolute. ${ }^{70}$ Michael Novak called Maritain the 'most holy philosopher he knew in his life. ${ }^{71}$ Maritain, in the book Integral Humanism, assumes that the awareness of the early mission of the Christian will bring forth a new style of holiness

60 CIPRO, Prameny výchovy. IV, 20. století..., p. 176.

61 RAJSKÝ, Univerzitné vzdelavanie ..., p. 6.

62 MARITAIN, Education at the Crossroads..., p. 75 (translated from the Czech version).

63 RAJSKÝ, Univerzitné vzdelavanie..., p. 7.

64 Karel ŠPRUNK, Rozlišovat ale neoddělovat - rozhovor s Karlem Šprunkem, Salve 2/2006, p. 47.

65 Jean Pierre TORRELL, Svatý Tomáš Akvinský, osoba a dílo, Prague: Krystal OP, 2017, p. 205.

66 Cf. HREHOVÁ, Morálna filozofia Jacquesa Maritaina..., p. 187.

67 Gerald A. McCOOL, S.J., From Unity to Pluralism: The Internal Evolution of Thomism, New York: Fordham University Press, 2002 , p. 116.

68 Jacques MARITAIN, Láska a prátelství, Prague: Krystal OP, 2005, p. 22.

69 Raïssa a Jacques MARITAINOVI, Stavy lidstva a svatosti, Prague: Krystal OP, 2011, p. 73.

70 Jacques MARITAIN, Přirozená mystická zkušenost a prázdnota, Salve 2/2006, p. 97.

71 Michael NOVAK, On Cultivating Liberty: Reflections on Moral Ecology, Lanham: Rowman \& Littlefield Publishers, Inc., 1999 , p. 186 (translated from the Czech version). 
which can be marked above all as holiness and sanctification of secular life. ${ }^{72}$ Maritain himself in his life become an example of profane holiness. It is necessary to become 'fools in the faith', to enter the state of foolish love for God. ${ }^{73}$ In his study Reflections of Three Philosophers, Donald A. Gallagher states how Maritain, in his letter to the Little Brothers of Jesus, proposes his new name 'Don Quixote of Saint Thomas' ${ }^{\text {' }}$ before his acceptance.

\section{Maritain's Neo-Thomistic Pedagogy}

The current multicultural, global society is still affected by relativism, a confusion of concepts and values, as Maritain called these ailments of his time in Integral Humanism. His warning of the problem of treating man as an object, consumerism, egoistic orientation, and technocracy is more than up-to-date. We have become their eyewitnesses. Today's time is witnessing the incompleteness of the concept of anthropocentric humanism. It does not fulfil the needs of the 21st century society and individual. Obviously, contemporary society must start being engaged with man as a person who is not part of a narrowly utilitarian but a cosmic order. This is one of the greatest parts of Maritain's entire thinking, of his intellectual heritage. Humanistic anthropology is becoming a challenge for contemporary pedagogy. Christianity, in this sense in our culture, has an absolutely privileged position. Maritain's philosophy of education can be attributed to Neo-Thomistic pedagogy, Christian (integral) personalism, the holistic educational concept, perennial formation-educational theory, and the pedagogy of values (pedagogy of culture).

Maritain's philosophy of education cannot be separated from his wider philosophical orientation which is derived from Thomas Aquinas, Aristotle, the Neoscholastics (e.g., Joaõ Poinsot) as well as from Christian authors such as St. Augustine and St. John of the Cross. Maritain saw education from the perspective of Neo-Thomistic philosophy (other representatives are, for example, W. Cunningham, E. Smith, M. Casotti). Maritain's books The Degrees of Knowledge (Les dégres du savoir, 1932) and Philosophy of Nature (La philosophie de la nature, 1935) are among the greatest manifestations of Thomism in the 20th century. In the area of Christian epistemology, there can be seen one of Maritain's greatest contributions to today's pedagogy. Maritain, thanks to his enormous erudition in the field of reflection on social and political issues (as seen, for example, in his works Integral Humanism (Humanisme intègral, 1936, 2nd edition 1946), Christianity and Democracy (Christianisme et Démocratie, 1943), and Man and the State (1951, L'Homme et l'Etat, 1953)), had sovereign prerequisites for reflecting the state of contemporary educational system and the level of education. He was intensively engaged in publishing activities in the field of pedagogy since 1943 in connection with the 'Terry Lectures' at Yale University. His perception of education from the perspective of Neo-Thomistic philosophy and his belief in the usefulness of applying Thomistic principles in educational institutions (including non-Catholic ones) contributed to the establishment of neo-Thomism as one of the philosophical movements in modern thinking regarding education. For the study of Maritain's Thomistic pedagogy the chapter 'Thomistic Opinions on Education' plays a key role, being part of the text of the books Pour une Philosophie de l'Éducation and The Education of Man: The Educational Philosophy of Jacques Maritain.

\footnotetext{
MARITAIN, Integrální humanismus..., p. 120.

MARITAIN, Láska a prátelství..., p. 19.

74 (c) Donald A. GALLAGHER, Recollections of Three Thinkers: Adler, Simon, and Maritain, available at: https://maritain.nd.edu/ama/ Torre/Torre04.pdf, cited 20 $0^{\text {th }}$ May 2018, p. 29.
} 


\section{Maritain's Personalistic, Integral Education}

As a representative of Neo-Thomistic personalism (for example, along with E. Gilson), he presents a personalistic view of formation and education with the priority of the principle of the person. The central point of Maritain's thinking was to distinguish between an individual and a person. It plays a fundamental role in his philosophy of education and his own pedagogical practice. The person becomes a centrepiece in his or her personal dimension of free self-possession and self-determination through reason and will. The concept of an individual person is the foundation of integral education which is necessary for the realisation of integral humanism. The latter represents the overcoming of the principle of individualism and totalitarianism/collectivism through the principle of personalistic civilisation. ${ }^{75}$ In the conclusion of Education at the Crossroads, Maritain said that 'American education is at a crossroads - it needs to be freed from the instrumentalism of pragmatic philosophy and replace it with a deeply personalistic integral humanism. ${ }^{76}$ Maritain is the peak of the Neo-Thomistic orientation of integral personalism. The integral approach helps the pupil to develop at several levels: it educates him as a whole, seeks to reintegrate him with the Creator, and integrates him into community and society. As the text of this article demonstrates, Maritain's pedagogical work is the fruit of the author's quest for an integral non-reducing form of education as a process and as an organised education system. ${ }^{77}$ The aim of integral education is the liberation of the individual through higher knowledge and wisdom, good will, and love; the basic mission of man is to be fully himself. According to Ján Letz, his personalism could have become a living principle of modern political activity thanks to Maritain's integral personalistic principle. ${ }^{78}$ We believe that it could play, with the knowledge of Maritain's pedagogical heritage, a similar role in the area of education.

\section{Maritain's Holistic and Perennial Approach}

One of the most striking features of Maritain's formation-educational concept is his holistic approach, focusing on the formation and education of the whole person. Together with Thomas Merton, Maritain was among the first promoters of this approach in pedagogy ${ }^{79}$ Maritain was a supporter of perennial education theory, which is based on the assumption that man naturally receives his or her own capability for knowledge and that he wants to find the truth. This ability is developed by leading the pupils to the collective experience of mankind through the cultural heritage contained in works of art, literature, philosophy, and science. Maritain focuses on the educational content of education and the passing on of the 'value memory of ancestors'. He concentrates on the system of values of the human spirit and heart. In this sense, he can be included among the representatives of the pedagogy of values (pedagogy of culture). Maritain's concept of integral humanism builds on the ancient tradition of humanism. In accord with the interpretation of Werner Jaeger in his work Paideia: The Ideals of Greek Culture (Paideia, Die Formung Des Griechischen Menschen, 1933), Maritain applies the pedagogical process to the ideals of truth, beauty, and goodness. Paideia is a process of education in which the imperative 'Know thyself' is the sense and purpose. Based on the texts of Maritain's pedagogical works, the author would

WIESENGANGER, Perspektívy filozofie výchovy..., p. 45.

MARITAIN, Education at the Crossroads..., p. 118 (translated from the Czech version).

WIESENGANGER, Perspektívy filozofie výchovy..., p. 42.

78 Ján LETZ, Personalistické metafyziky: Křestanská filozofia 20. storočia a jej perspektivy, Trnava: Typi Universitatis Tyrnaviensis, 2006, p. 102.

79 IBARRA, Maritain, Religion and Education..., p. 143. 
undoubtedly support the text of the 'Paideia Proposal' by Mortimer J. Adler published in 1982. It presents the reform of American state education. The same suggestion in the contemporary philosophy of education can be found in the heritage of Agustin Basave Fernández del Valle (+2006) who offers an integral philosophy of education, respectively a new paideia that is enriched by the personalistic dimension of love (Filosofia Integral de la Educación: una Nueva Paideia, 1998; Integral Philosophy of Education: A New Paideia). ${ }^{80}$ Maritain's belief in knowing by love (per amorem cognoscimus) and the need to educate with love is a categorical imperative. Otherwise, the world will not be inhabited by man. There is nothing more magnificent for man than intuition and love which (like wisdom) cannot be taught. ${ }^{81}$

\section{Conclusion}

The personal-essential core is increasingly disappearing from the identity of contemporary man. Maritain's call for the holistic identity of man and the realisation of the identity mediated by Christ is becoming more and more up to date. His pedagogical concept guarantees the individual identity of every person and universal solidarity. His work remains the universal timeless message of 'caritas humani generis'. He left us a message which is an appeal. We should be aiming at the resurrection of the spiritual life and the genuine commitment to the ideal of the new Christianity and the new man: the rebirth of formation and education 'sub speciae aeternitatis' - in the spirit of integral humanism.

\section{Contact}

\section{Assoc. Prof. PhDr. Helena Zbudilová, Ph.D.}

University of South Bohemia in České Budějovice, Faculty of Theology,

Department of Pedagogy

Kněžská 8, 37001 České Budějovice

hzbudilova@tf.jcu.cz

80 Sabína GÁLIKOVÁ TOLNAIOVÁ, Problém výchovy na prahu 21. storočia, Bratislava: Iris, 2007, p. 146.

81 CIPRO, Prameny výchovy. IV, 20. století..., p. 172. 